\title{
Staff Nurses' Burnout and Job Satisfaction and its Relation to Patients' Satisfaction in Port Said Hospitals
}

\author{
Prof. Eman Salman Taie; Assistant Prof. Mona Abdelsabour Hassan; Hanaa \\ Mohamed Abdelsalam \\ Professor of Nursing Administration - Faculty of Nursing - Helwan University; \\ Assistant Professor of Community and Family Health Nursing - Faculty of Nursing - \\ Port Said University; Nursing Specialist - Port Said General Hospital
}

\begin{abstract}
Background: Burnout remains a significant concern in nursing, affecting both nurses and patients. The stressful nature of nursing profession can lead to job dissatisfaction and burnout. Aim: This study is aimed to measure staff nurses' burnout, job satisfaction and their relation to patient satisfaction in Port Said hospitals. Design: A descriptive correlational research design was conducted in this study. Sample: The subjects of this study consisted of two groups: First group : nurses, they were (310) nurses from the selected hospitals. Second group: patients, they were (116) patients from the selected hospitals. Tools: Data were collected using a questionnaire sheet containing three tools, first tool Maslach burnout inventory, second tool job satisfaction scale, and finally patient satisfaction questionnaire sheet. Results: The study results revealed that more than half of total nurses $(59.52 \%)$ were burned out in both studied hospitals, nearly half of total nurses (43.49\%) were dissatisfied with job in both studied hospitals. Conclusion: There was a statistically significant negative correlation between total burnout, total job satisfaction, and patients' satisfaction levels at both of the studied hospitals. Recommendations: The study recommended to provide measures to reduce the workload on nurses and appropriate interventions should be conducted including their salary and improving work condition.
\end{abstract}

Keywords: Burnout, Job satisfaction, Patient satisfaction 


\section{INTRODUCTION}

Nursing is a stressful profession that deals with intense human aspects of health and illness. Consequently, the stressful nature of nursing profession can ultimately lead to job dissatisfaction and burnout. Among health care professionals, nurses have been found to be most prone to burnout. Job satisfaction and burnout among health care providers are important issues since they affect turnover rates, staff retention and ultimately the patient satisfaction (Westermann \& Kozak \& Harling \& Nienhaus, 2014).

Burnout is defined as a phenomenon that is of interest for both individuals and organizations, is characterized by decreasing energy, power and resources in the presence of excessive demands. It is one of the factors which influence the efficiency and productivity of the workers and staff in every field (Khodadadizadeh. et al 2012). There are several factors that is affecting burnout for nurses; as workload, community, reward, control, fairness, values, perfectionism, client diagnoses, and work-setting (Pineau Stam. et al 2013).

Sharma (2012), defined Job satisfaction as the whole matrix of job factors that make a person like his work situation and be willing to head for it without distaste at beginning of his workday. Wilson. et al (2010), also pointed out that job satisfaction is an employee's feeling about his or her job and is a general attitude derived from an evaluation of all aspects in a job. Many factors are reported to affect job satisfaction among nurses such as turnover, absenteeism, shortage of nursing personnel, poor planning, unclear rules of regulation, unreasonable pressure, understaffing non nursing duties, inadequate explanation of decision affecting job, work load negatively affecting work quality (Yusof. et al 2013).

Recent research indicated that the component of burnout is strongest predictor of job dissatisfaction, plans for leaving the job, training for other work, and actual turnover. Gilles (2009), mentioned that shortage of nursing personnel and turnover is associated with dissatisfaction and also contributed to low productivity, consume time and money that are required to recruit and select a replacement for someone who leaves a position. 
Patient satisfaction is the degree to which the patient's desired expectations, goals and or preferences are met by the health care provider and or service. There are main dimensions related to patient satisfaction; physical environment, physical accessibility, time accessibility, financial accessibility, quality of care and equipments, personnel's social interaction, and equity (Hatamizadeh. et al 2011).

Nurses report better job satisfaction when they are working in an environment in which there is adequate staffing and support from other nurses, this leads to decrease nurse burnout, better quality of patient care and increase patient satisfaction (Nantsupawat 2011). Improvements in nurses' work environments in hospitals have the potential to simultaneously reduce nurses' high levels of job burnout and risk of turnover and increase patients' satisfaction with their care. Higher nurse workloads are associated with burnout and job dissatisfaction, precursors to voluntary turnover that contributes to under staffing of nurses in hospitals and poorer patients satisfaction and outcome (Lasebikan \& Oyetunde 2012).

\section{Significance of the study:}

Burnout is considered to have a negative effect on job and life satisfaction. Lack of job satisfaction and the exhaustion is a factor that has a negative impact on the quality of the service that nurses provide it for patients; so job satisfaction and exhaustion levels for nurses continue to be a current matter that attracts the attention of researchers. In many studies it was reported that there was a negative relationship between job satisfaction and exhaustion levels of nurses, so the satisfaction and exhaustion level of the individual in work life is a factor that affect the quality of the service the individual provides (Sheward. et al 2005; Tarihi 2010; Aiken. et al 2010).

\section{AIM OF THE STUDY:}

This study aims to measure staff nurses' burnout and job satisfaction and its relation to patient satisfaction in Port Said hospitals. 


\section{Research questions:}

1-What are the levels of burnout for nurses working at two selected hospitals in Port Said?

2- What is the level of job satisfaction for nurses working at two selected hospitals?

3- What are the level of patients satisfaction at two selected hospitals?

4- Is there is a relationship between nurses' burnout, job satisfaction and patient satisfaction at two selected hospitals

\section{SUBJECTS AND METHODS:}

\section{Research Design:}

A descriptive correlational research design was used in this study.

\section{TECHNICAL DESIGN:}

\section{Study Setting:}

This study was carried out at two hospitals (Port Said general hospital - Al-Soliman hospital). Port Said general hospital which affiliated to governmental sector (ministry of health), while Al-Soliman hospital affiliated to private sector. All hospital units were included in the present study and excluded hemodialysis and out patients units.

\section{Study Subjects:}

The subjects of this study consisted of two groups:

\section{1- Nurses group:}

All staff nurses in the selected two hospitals were included in the study $(\mathrm{N}=310)$ nurses, PortSaid hospital (230) nurses, while Al-Soliman hospital (80) nurses.

\section{*Inclusion criteria:}

Nurses with at least one year of experiences in their current job.

\section{2- Patients group:}

The numbers of patients were (116) in the selected hospitals divided according to the number of beds at two selected hospitals in port said to be as follow:

1-Al-Soliman hospital (58) patient.

2-Port said general hospital (58) patient. 


\section{*Inclusion criteria:}

Patients in an inpatient units, length of patients stayed at least 5days.

\section{*Exclusion Criteria:}

Patients' unable to communicate due to bad general condition as (comatosed patients-critically ill patients), patients in hemodialysis unit, and patients of outpatient units.

\section{TOOL FOR DATA COLLECTION:}

The study data was collected by using three tools, two tools for nurses and one tool for patients, which were:

\section{1-Maslach burnout inventory (MBI) for nurses:}

The Maslach burnout inventory was developed by (Maslach and Jackson 1981) to assess the burnout level among nurses, it was translated into Arabic to suite the Egyptian culture and revised by experts for content validity, It consists of two parts:

The first part of this tool included personal and job characteristics of the selected study sample as their ( age, gender, marital status, level of education, years of experiences, working department, number of working hours per day, average number of patients cared per day).

The second part: provided a measure of perceived burnout of three subscales;

I-Professional depression; it included (17) items.

II-Personal accomplishment; it included (8) items.

III-Emotional exhaustion; it included (17) items.

\section{Scoring system:}

The numerical rating assigned to the item was transposed into (2) for Yes and (1) for NO. There were high levels of burnout if the percent score was $60 \%$ or more and low levels if less than $60 \%$.

This tool was tested for its validity and reliability by using r: Pearson coefficient, *: Statistically significant at $\mathrm{p} \leq 0.05$ and Cronbach's techniques which indicated that the alpha for burnout was (0.842). 
2-Job Satisfaction Scale for nurses: It developed by (Spector 1997) to assess job satisfaction of nurses. The tool translated by researcher to suit the egyptian culture and tested by five experts. The modifications were done according to openions of the experts. The scale consisted of (36) structured items that measure the job satisfaction.

It consisted of nine facets (4) items for each facet was the following:

Payment - Promotion - Supervision - Fringe benefits - Contingent Rewards Operating procedures - Coworkers relationship - Nature of work - Communication

\section{Scoring system:}

Each item described a potential satisfying or dissatisfying factor toward the nursing job. Respondents' answered for each item were rated on a three - point scale ranging from "strongly disagree"(1) to "strongly agree"(3).

\section{The score system was considered:}

- Low if the score was less than 50.

- High if the score was more than 50 .

This tool was tested for its validity and reliability by using r: Pearson coefficient, *: Statistically significant at $\mathrm{p} \leq 0.05$ and Cronbach's techniques which indicated that the alpha for job satisfaction was (0.77).

3-Patient Satisfaction Questionnaire: It was developed by (Woodard 2009) to measure patient satisfaction, translated by researcher to suit the Egyptian culture modified and revised by five experts for content validity, it consisted of five dimensions with (35) items as following:

1- Access (Reception of patients): it included (8) items.

2 - Nurses: it included (10) items.

3- Doctors: it included (8) items.

4- Facilities: it included (4) items.

5- Catering (Food services): it included (5) items. 


\section{Scoring system:}

Each item described a potential satisfying or dissatisfying factor toward hospital services .Respondents answered for each item were rated on three point scale ranging from "Disagree" (1) to "Agree" (3) .

\section{The score system was considered:}

_ Low if the score was less than 40.

_ High if the score was more than 40.

This tool was tested for its validity and reliability by using r: Pearson coefficient, *: Statistically significant at $\mathrm{p} \leq 0.05$ and Cronbach's techniques which indicated that the alpha for patient satisfaction was (0.853).

\section{OPERATIONAL DESIGN}

The operational design involves discussion of the content validity, reliability of tool, pilot study and the field work.

\section{Pilot Study:}

The investigator conducted a pilot study using the data collection tool on (31) nurses and (11) patients from the two selected hospitals, for evaluating the content, clarity and applicability of questionnaire, it was conducted at the time from first of 5/2014 to end of 7/2014 before embarking on the field work of the main study, reconstruct the questionnaire and manage time needed to fulfill the entire needed tool, the time to filling the tool was estimated to be from (25-30) minutes for the questionnaire sheet for each nurse and each patient, based on the result of pilot study, the necessary modifications for some parts of the tool were done, and the finalized forms were developed, Pilot study sample wasn't included in the main study sample.

\section{Field Work:}

This stage includes collection of data. Data were collected by the researcher from nurses and patients, data collection was completed over a period of three months from first of 5/2014 to end of 7/2014, during the morning or afternoon shifts, according to the time available to participants. Before distributing the questionnaire sheet clear instructions were given to every participant about the purpose of the study. The 
questionnaire sheets were distributed and collected in the same day. Each questionnaire sheet took about (25-30) minutes to be fulfilled in. The researcher checked each questionnaire sheet after being completed by the participants to ensure the completion of all items.

\section{ADMINISTRATIVE DESIGN:}

An official letters directed from the dean of Faculty of Nursing in Port Said University to medical and nursing directors of the premonitioned hospitals to obtain their permissions for conducting this study. written permission obtained from selected hospitals for taking nurses who works on the medical, surgical, obstetric, orthopedic and I. C. U departments in the hospitals .

\section{Ethical Considerations:}

A brief explanation of the aim of the study was given to director, head nurse, and each nurse's and patients participant in the study. An agreement of participation was taken from nurses who involved in this study, after explanation of the purpose of this study for each of them. Every patient in the study was assured individually, that the information obtained will be confidential, will not affect the care given to him/her and it will be used only for the research purposes. The researcher emphasized that participation were absolutely voluntary and each nurse have the right to withdraw from the study at any time and confidentiality was assured.

\section{STATISTICAL DESIGN:}

Data were presented using descriptive statistics in the form of frequencies and percentage for qualitative variables, and means and standard deviations for quantitative variables were compared using chi-square test. Pearson correlation analysis was used for assessment of the interrelationships among quantitative variables.

\section{RESULTS:}

Table (1): Reveals that nearly half of the total sample of the studied nurses (46.5\%) were aged less then 30 years. $43.9 \%$ of the total sample had experience more than (10) years, most of the total sample (72.9\%)were working six hours /day , $70.0 \%$ of the total sample were responsible for less (10) patients per shift. 
Table (2): Shows the highest mean score of burnout of the total sample $(64.8 \%)$ was in area of professional depression, the lowest one $(81.3 \%)$ was in area of personal accomplishment in port said hospital.

Table (3): Presents the highest mean scores of job satisfaction of the total sample were detected in areas of promotion (41.6\%), while the lowest mean scores were in areas of operating procedures $(85.2 \%)$.

Table (4): Shows the statistical significant negative correlation between total burn out and all areas of job satisfaction except areas of contingent rewards and operating procedures $(\mathrm{p}=0.089$ and 0.415 ).

Table (5): demonstrates the highest mean scores of patient satisfaction of the total sample were detected in areas of nurse (92.2\%), while the lowest mean scores were in areas of facilities $(73.3 \%)$.

Table (6): reveals correlation between Patient's satisfaction with nurses satisfaction and nurses burnout at selected hospitals, the results shows that there is no statistically significant correlation between Access(reception of patients), Facilities, Catering (food services) and job satisfaction and burnout. Moreover, there is no statistically significant correlation between nurses and burnout and job satisfaction except areas of supervision, Emotional Exhaustion and the total burnout $\left(\mathrm{P}=0.035^{*}\right.$, $\left.0.042^{*}, 0.024^{*}\right)$. Also there is no statistically significant correlation between doctors, job satisfaction and burnout except area of nature work $\left(\mathrm{P}=0.001^{*}\right)$. 
Table (1): The studied nurses according to personal \& job characteristics at studied hospitals:

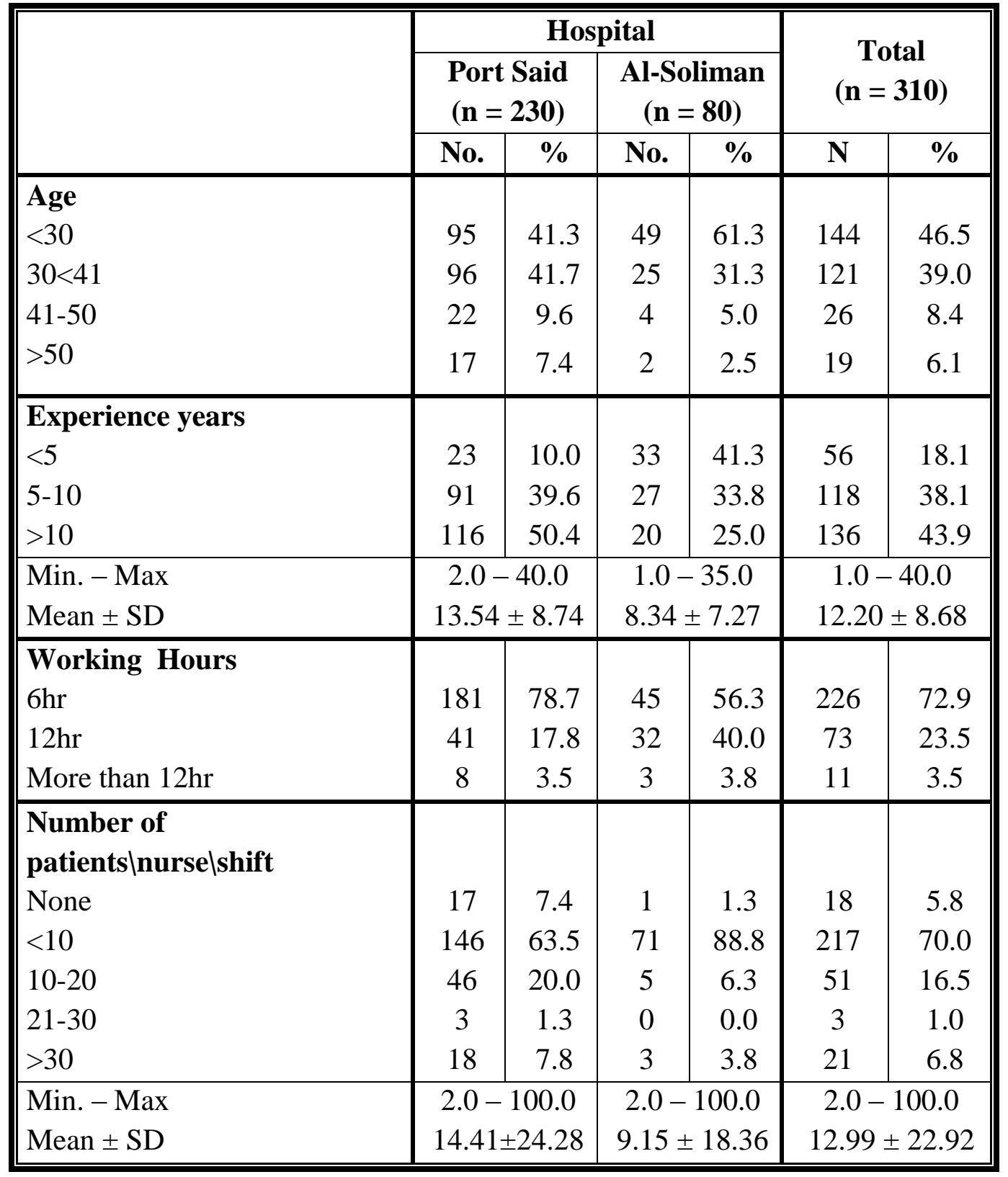


Table (2): The mean score of burnout for the studied nurses at the selected hospitals:

\begin{tabular}{|c|c|c|c|c|c|c|c|c|c|c|c|c|c|c|}
\hline & \multicolumn{4}{|c|}{ Port Said $(n=230)$} & \multicolumn{4}{|c|}{ Al-Soliman $(n=80)$} & \multirow{3}{*}{$\chi^{2}$} & \multirow{3}{*}{$\mathbf{p}$} & \multicolumn{4}{|c|}{ Total $(n=310)$} \\
\hline & \multicolumn{2}{|c|}{$<60 \%$ low } & \multicolumn{2}{|c|}{$\geq 60 \%$ high } & \multicolumn{2}{|c|}{$<60 \%$ low } & \multicolumn{2}{|c|}{$\geq 60 \%$ high } & & & $<60 c$ & low & $\geq 60 \%$ & o higl \\
\hline & No. & $\%$ & No. & $\%$ & No. & $\%$ & No. & $\%$ & & & No. & $\%$ & No. & $\%$ \\
\hline $\begin{array}{l}\text { Professional } \\
\text { Depression }\end{array}$ & 73 & 31.7 & 157 & 68.3 & 36 & 45.0 & 44 & 55.0 & $4.578^{*}$ & $0.032^{*}$ & 109 & 35.2 & 201 & 64.8 \\
\hline $\begin{array}{l}\text { Personal } \\
\text { Accomplishment }\end{array}$ & 181 & 78.7 & 49 & 21.3 & 71 & 88.8 & 9 & 11.3 & $3.945^{*}$ & $0.047^{*}$ & 252 & 81.3 & 58 & 18.7 \\
\hline $\begin{array}{l}\text { Emotional } \\
\text { Exhaustion }\end{array}$ & 84 & 36.5 & 146 & 63.5 & 38 & 47.5 & 42 & 52.5 & 2.997 & 0.083 & 122 & 39.4 & 188 & 60.6 \\
\hline Total Burnout & 95 & 41.3 & 135 & 58.7 & 56 & 70.0 & 24 & 30.0 & 19.563 & $<0.001^{*}$ & 151 & 48.7 & 159 & 51.3 \\
\hline
\end{tabular}

$*$ : Statistically significant at $p \leq 0.05$

Table (3): The mean score of job satisfaction for the studied nurses at the selected hospitals:

\begin{tabular}{|c|c|c|c|c|c|c|c|c|c|c|c|c|c|c|}
\hline & \multicolumn{8}{|c|}{ Hospital } & \multirow{4}{*}{$\chi^{2}$} & \multirow{4}{*}{$\mathbf{p}$} & \multirow{2}{*}{\multicolumn{4}{|c|}{ Total $(n=310)$}} \\
\hline & \multicolumn{4}{|c|}{ Port Said $(n=230)$} & \multicolumn{4}{|c|}{ Al-Soliman $(\mathbf{n}=\mathbf{8 0})$} & & & & & & \\
\hline & \multicolumn{2}{|c|}{$\leq \mathbf{5 0 \%}$ low } & \multicolumn{2}{|c|}{$\begin{array}{c}>\mathbf{5 0} \% \\
\text { high }\end{array}$} & \multicolumn{2}{|c|}{$\begin{array}{c}\leq 50 \% \\
\text { low }\end{array}$} & \multicolumn{2}{|c|}{$\begin{array}{c}>\mathbf{5 0 \%} \\
\text { high }\end{array}$} & & & \multicolumn{2}{|c|}{$\leq \mathbf{5 0 \%}$ low } & \multicolumn{2}{|c|}{$>\mathbf{5 0 \%}$ high } \\
\hline & No. & $\%$ & No. & $\%$ & No. & $\%$ & No. & $\%$ & & & No. & $\%$ & No. & $\%$ \\
\hline Payment & 196 & 85.2 & 34 & 14.8 & 40 & 50.0 & 40 & 50.0 & $40.509^{*}$ & $<0.001^{*}$ & 236 & 76.1 & 74 & 23.9 \\
\hline Promotion & 128 & 55.7 & 102 & 44.3 & 53 & 66.3 & 27 & 33.8 & 2.744 & 0.098 & 181 & 58.4 & 129 & 41.6 \\
\hline Supervision & 207 & 90.0 & 23 & 10.0 & 53 & 66.3 & 27 & 33.8 & $24.749^{*}$ & $<0.001^{*}$ & 260 & 83.9 & 50 & 16.1 \\
\hline Fringe Benefits & 167 & 72.6 & 63 & 27.4 & 59 & 73.8 & 21 & 26.3 & 0.039 & 0.843 & 226 & 72.9 & 84 & 27.1 \\
\hline Contingent & 184 & 80.0 & 46 & 20.0 & 55 & 68.8 & 25 & 31.3 & $4.254^{*}$ & $0.039^{*}$ & 239 & 77.1 & 71 & 22.9 \\
\hline $\begin{array}{l}\text { Operating } \\
\text { procedures }\end{array}$ & 197 & 85.7 & 33 & 14.3 & 67 & 83.8 & 13 & 16.3 & 0.170 & 0.680 & 264 & 85.2 & 46 & 14.8 \\
\hline $\begin{array}{l}\text { Coworkers } \\
\text { relationship }\end{array}$ & 140 & 60.9 & 90 & 39.1 & 44 & 55.0 & 36 & 45.0 & 0.848 & 0.357 & 184 & 59.4 & 126 & 40.6 \\
\hline Nature work & 187 & 81.3 & 43 & 18.7 & 58 & 72.5 & 22 & 27.5 & 2.776 & 0.096 & 245 & 79.0 & 65 & 21.0 \\
\hline $\begin{array}{l}\text { Communicatio } \\
\text { n }\end{array}$ & 191 & 83.0 & 39 & 17.0 & 64 & 80.0 & 16 & 20.0 & 0.377 & 0.539 & 255 & 82.3 & 55 & 17.7 \\
\hline $\begin{array}{l}\text { Total } \\
\text { Satisfaction }\end{array}$ & 175 & 76.1 & 55 & 23.9 & 45 & 56.3 & 35 & 43.8 & $11.336^{*}$ & $0.001^{*}$ & 220 & 71.0 & 90 & 29.0 \\
\hline
\end{tabular}

$\chi^{2}, p: \chi^{2}$ and $p$ values for Chi square test

$*$ : Statistically significant at $\mathbf{p} \leq \mathbf{0 . 0 5}$ 
Table (4): Correlation between burnout and job satisfaction for total sample of the studied nurses $(\mathrm{n}=310)$

\begin{tabular}{|c|c|c|c|c|c|}
\hline & & $\begin{array}{l}\text { Professional } \\
\text { Depression }\end{array}$ & $\begin{array}{c}\text { Personal } \\
\text { Accomplishment }\end{array}$ & $\begin{array}{c}\text { Emotional } \\
\text { Exhaustion }\end{array}$ & $\begin{array}{c}\text { Total } \\
\text { Burnout }\end{array}$ \\
\hline \multirow{2}{*}{ Payment } & $\mathbf{r}$ & $-0.159^{*}$ & $-0.297^{*}$ & -0.101 & $-0.226^{*}$ \\
\hline & $\mathbf{p}$ & 0.005 & $<0.001$ & 0.077 & $<0.001$ \\
\hline \multirow{2}{*}{ Promotion } & $\mathbf{r}$ & -0.066 & $-0.277^{*}$ & $-0.150^{*}$ & $-0.191^{*}$ \\
\hline & $\mathbf{p}$ & 0.245 & $<0.001$ & 0.008 & 0.001 \\
\hline \multirow{2}{*}{ Supervision } & $\mathbf{r}$ & $-0.162^{*}$ & $-0.317^{*}$ & -0.110 & $-0.238^{*}$ \\
\hline & $\mathbf{p}$ & 0.004 & $<0.001$ & 0.054 & $<0.001$ \\
\hline \multirow{2}{*}{ Fringe Benefits } & $\mathbf{r}$ & $-0.229^{*}$ & -0.101 & -0.082 & $-0.201^{*}$ \\
\hline & $\mathbf{p}$ & $<0.001$ & 0.076 & 0.147 & $<0.001$ \\
\hline \multirow{2}{*}{ Contingent rewards } & $\mathbf{r}$ & -0.021 & $-0.314^{*}$ & 0.013 & -0.097 \\
\hline & $\mathbf{p}$ & 0.707 & $<0.001$ & 0.826 & 0.089 \\
\hline \multirow{2}{*}{ Operating procedures } & $\mathbf{r}$ & -0.006 & $-0.150^{*}$ & 0.0 & -0.046 \\
\hline & $\mathbf{p}$ & 0.921 & 0.008 & 1.000 & 0.415 \\
\hline \multirow{2}{*}{ Coworkers relationship } & $\mathbf{r}$ & $-0.133^{*}$ & $-0.349^{*}$ & $-0.143^{*}$ & $-0.246^{*}$ \\
\hline & $\mathbf{p}$ & 0.020 & $<0.001$ & 0.012 & $<0.001$ \\
\hline \multirow{2}{*}{ Nature of work } & $\mathbf{r}$ & -0.081 & $-0.237^{*}$ & -0.062 & $-0.145^{*}$ \\
\hline & $\mathbf{p}$ & 0.153 & $<0.001$ & 0.273 & 0.010 \\
\hline \multirow{2}{*}{ Communication } & $\mathbf{r}$ & $-0.172^{*}$ & $-0.291^{*}$ & $-0.144^{*}$ & $-0.253^{*}$ \\
\hline & $\mathbf{p}$ & 0.002 & $<0.001$ & 0.011 & $<0.001$ \\
\hline \multirow{2}{*}{ Total Satisfaction } & $\mathbf{r}$ & $-0.190^{*}$ & $-0.421^{*}$ & $-0.141^{*}$ & $-0.299^{*}$ \\
\hline & $\mathbf{p}$ & 0.001 & $<0.001$ & 0.013 & $<0.001$ \\
\hline
\end{tabular}

r: Pearson coefficient

*: Statistically significant at $\mathbf{p} \leq \mathbf{0 . 0 5}$ 
Table (5): The mean of level of satisfaction of the studied patients in Port Said \& Al-

Soliman hospitals:

\begin{tabular}{|c|c|c|c|c|c|c|c|c|c|c|c|c|}
\hline & \multicolumn{4}{|c|}{ Port Said $(n=58)$} & \multicolumn{4}{|c|}{ AL-Soliman $(n=58)$} & \multicolumn{4}{|c|}{ Total $(n=116)$} \\
\hline & \multicolumn{2}{|c|}{$<40 \%$ low } & \multicolumn{2}{|c|}{$\geq 40 \%$ high } & \multicolumn{2}{|c|}{$<40 \%$ low } & \multicolumn{2}{|c|}{$\geq 40 \%$ high } & \multicolumn{2}{|c|}{$<40 \%$ low } & \multicolumn{2}{|c|}{$\geq 40 \%$ high } \\
\hline & No. & $\%$ & No. & $\%$ & No. & $\%$ & No. & $\%$ & No. & $\%$ & No. & $\%$ \\
\hline Access & 31 & 53.4 & 27 & 46.6 & 19 & 32.8 & 39 & 67.2 & 50 & 43.1 & 66 & 56.9 \\
\hline Nurse & 4 & 6.9 & 54 & 93.1 & 5 & 8.6 & 53 & 91.4 & 9 & 7.8 & 107 & 92.2 \\
\hline Doctors & 13 & 22.4 & 45 & 77.6 & 10 & 17.2 & 48 & 82.8 & 23 & 19.8 & 93 & 80.2 \\
\hline Facilities & 37 & 63.8 & 21 & 36.2 & 48 & 82.8 & 10 & 17.2 & 85 & 73.3 & 31 & 26.7 \\
\hline Catering & 44 & 75.9 & 14 & 24.1 & 15 & 25.9 & 43 & 74.1 & 59 & 50.9 & 57 & 49.1 \\
\hline $\begin{array}{l}\text { Total } \\
\text { Satisfaction }\end{array}$ & 5 & 8.6 & 53 & 91.4 & 12 & 20.7 & 46 & 79.3 & 17 & 14.7 & 99 & 85.3 \\
\hline
\end{tabular}

Table (6): Correlation between Patient's satisfaction with nurses satisfaction and nurses burnout at selected hospitals

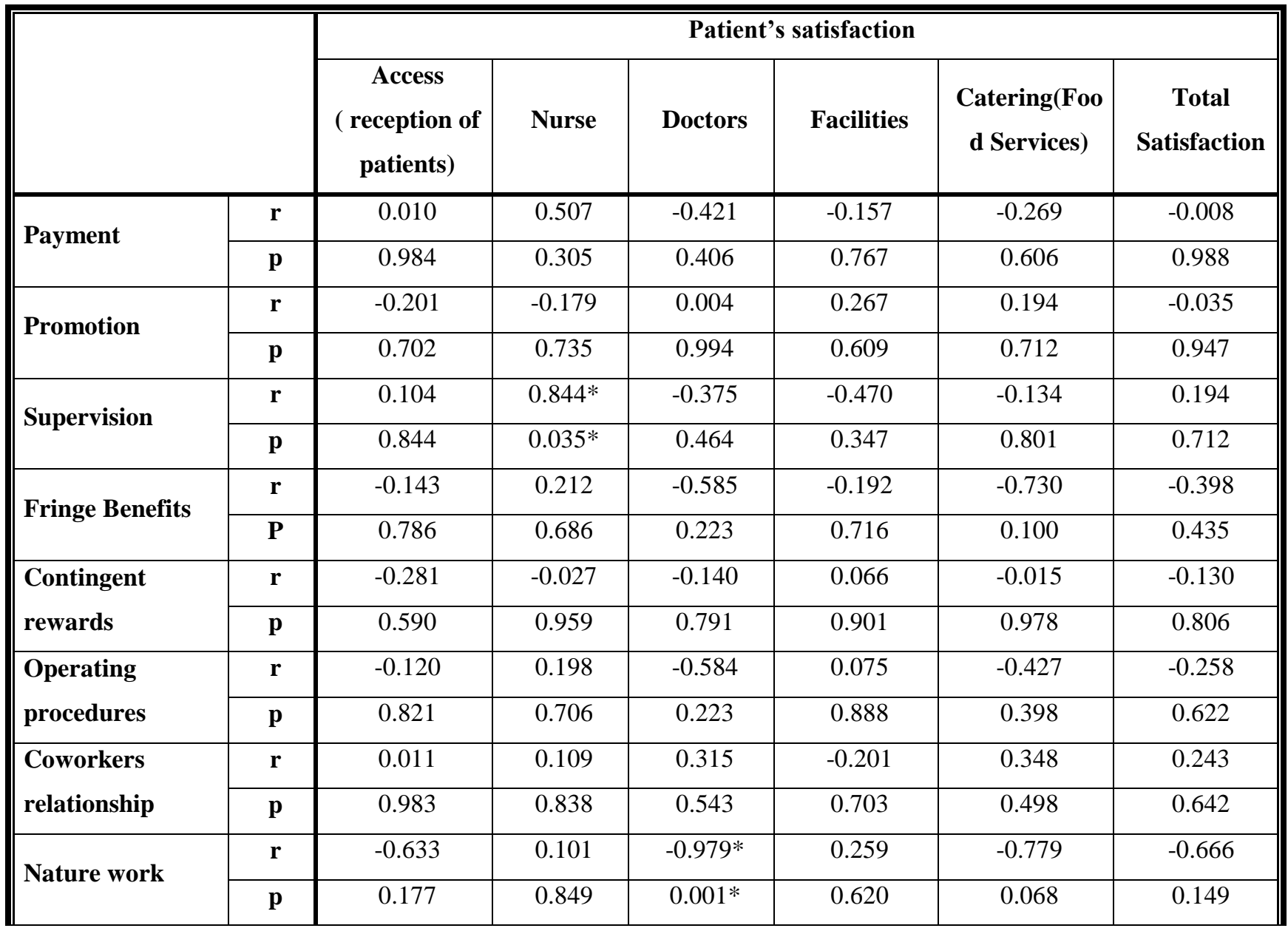




\begin{tabular}{|c|c|c|c|c|c|c|c|}
\hline \multirow{2}{*}{ Communication } & $\mathbf{r}$ & -0.482 & 0.047 & -0.694 & 0.558 & -0.231 & -0.335 \\
\hline & $\mathbf{p}$ & 0.333 & 0.930 & 0.126 & 0.250 & 0.660 & 0.516 \\
\hline \multirow{2}{*}{$\begin{array}{l}\text { Total job } \\
\text { Satisfaction }\end{array}$} & $\mathbf{r}$ & -0.368 & 0.431 & -0.755 & 0.004 & -0.449 & -0.291 \\
\hline & $\mathbf{p}$ & 0.473 & 0.393 & 0.083 & 0.994 & 0.372 & 0.576 \\
\hline \multirow{2}{*}{$\begin{array}{l}\text { Professional } \\
\text { Depression }\end{array}$} & $\mathbf{r}$ & -0.254 & -0.786 & 0.369 & 0.473 & 0.248 & -0.172 \\
\hline & $\mathbf{p}$ & 0.628 & 0.064 & 0.472 & 0.344 & 0.636 & 0.745 \\
\hline \multirow{2}{*}{$\begin{array}{l}\text { Personal } \\
\text { Accomplishment }\end{array}$} & $\mathbf{r}$ & -0.078 & -0.464 & -0.039 & 0.484 & -0.069 & -0.208 \\
\hline & $\mathbf{p}$ & 0.883 & 0.354 & 0.942 & 0.331 & 0.897 & 0.692 \\
\hline \multirow{2}{*}{$\begin{array}{l}\text { Emotional } \\
\text { Exhaustion }\end{array}$} & $\mathbf{r}$ & -0.199 & $-0.828 *$ & 0.370 & 0.325 & 0.056 & -0.260 \\
\hline & $\mathbf{p}$ & 0.705 & $0.042 *$ & 0.470 & 0.529 & 0.916 & 0.618 \\
\hline \multirow{2}{*}{ Total Burnout } & $\mathbf{r}$ & -0.243 & $-0.871 *$ & 0.358 & 0.492 & 0.158 & -0.240 \\
\hline & $\mathbf{p}$ & 0.643 & $0.024 *$ & 0.485 & 0.322 & 0.764 & 0.648 \\
\hline
\end{tabular}

r: Pearson coefficient

*: Statistically significant at $\mathbf{p} \leq \mathbf{0 . 0 5}$

\section{DISCUSSION:}

Exhaustion and lack of job satisfaction are factors that affect patients. Both job satisfaction and exhaustion levels of nurses continue to be a current matter that attracts the attention of researchers (Aiken et.al. 2010; Wong 2012; Pineau Stam 2013). The present study was performed to measure staff nurses' burnout and job satisfaction and their relation to patients' satisfaction in Port Said hospitals.

The current study showed that nurses' burnout has a negative effect upon both the job satisfaction and quality of nursing services. This finding was in agreement with the findings of Happell (2009); Hakanen \& Schanfeli (2012); Bakker \& Demerouti (2014) who indicated that components of burnout lead to job dissatisfaction, planning for leaving the job and risk to patients. The present study also revealed that there was a negative correlation between nurses' burnout and job satisfaction at the studied hospitals which affect patients' satisfaction.

The present study showed that there were statistically significant differences between two hospitals in total burnout and in all areas of burnout, namely professional depression, emotional exhaustion and personal accomplishment. These were supported by Edwards \& Burnard (2004); Sandstorm et.al. (2011); Bakker et.al. (2014) who indicated that significant differences were found in emotional exhaustion and personal 
accomplishment among nurses. Actually, burnout may lead to the nurse's exhaustion, decrease in personal achievement, stress, and a feeling of depression.

The current study demonstrated that nurses in Al-Soliman Hospital were satisfied with their job and that burnout was lower than nurses in Port Said Hospital. These results were on the line with Giacaman (2000); Atencio et.al. (2005); Abushaikha \& Hazboun (2009); Wachter (2010) \& Leiter et.al. (2014) who stated that nurses in private health care settings were satisfied with their job. The researcher believes that this result may be attributed to structural and functional differences between private and governmental hospitals. Private hospitals offer better facilities, higher salaries, more incentives, and superior working conditions to nurses in comparison with governmental hospitals, which usually have workload, and limited financial and human resources to employees.

The results of this study revealed that there were statistically significant differences among the studied hospitals in all areas of job satisfaction; except areas of promotion and coworker relationship. These results were inconsistent with Nakakis and Ouzouni (2008); Laschinger et.al. (2012); Bakker et.al. (2014) who found significant difference in job satisfaction among nurses in different hospitals.

Results of the current study recorded that a statistical significant negative correlation was found between emotional exhaustion and all areas of job satisfaction. These results were supported by Vahey and Alkon (2010); Schanfeli and Hakanen (2012); Breevaart et.al. (2014) who stated that all burnout subscales were strongly related to job satisfaction.

The current study revealed that the total mean score of patients' satisfaction is higher in Al-Soliman Hospital than in Port Said Hospital. These findings of the current study were on the same line with El-Awa et.al. (2011); Aldaqal et.al. (2012); Suresh et.al. (2013) who showed that patients in private hospitals were more satisfied with nursing care than patients in governmental hospitals, a statistically significant differences were found between the two hospitals. 
Finally, the present study demonstrated that patients' satisfaction levels are lower in hospitals with nurses who are dissatisfied and burned out. These results were supported by Norton et.al. (2010) ; Fry (2011) ; Pawan \& Suresh (2013) who reported that high levels of burnout and job dissatisfaction among hospital nurses were associated with lower patients' satisfaction, which signals problems with care quality.

\section{CONCLUSION:}

There was a statistically significant negative correlation between nurses' burnout and job satisfaction in both studied hospitals (Port Said General Hospital and AlSoliman Hospital) and it affect patients' satisfaction. Nurses' burnout were higher in Port Said general hospital than in Al-Soliman Hospital. Nearly half of total nurses were dissatisfied with job in both studied hospitals, nurses' dissatisfaction was higher in Port Said Hospital. Patients' satisfaction was low in both studied hospitals where many nurses feel burned out and dissatisfied with their work conditions. Patients' dissatisfaction was higher in Port Said hospital than Al-Soliman Hospital.

\section{RECOMMENDATIONS:}

1- Health care administrators should improve nurses' working conditions to help in improvement of nurse satisfaction as well as the quality of care.

2- Develop in service-training programs to enhance staff development and to lower stress and anxiety levels.

3- Periodic check for nurses' satisfaction using standardized evaluation tool to determine levels and causes of nurses' dissatisfaction.

4- Public hospitals need to implement effective measures to improve patient's satisfaction.

5- Periodic check for patients' satisfaction using standardized evaluation tool to determine levels and causes of patients' dissatisfaction.

6- Further researches are needed to discover relevant factors that contribute to burnout and job satisfaction among nurses all over the country. 


\section{REFERENCES:}

Abushaikha, L, \& Hazboun.(2009): Job satisfaction and burnout among Palestinian nurses , La Revue de santé de la Mediterranean Orientale, Val 15, No 1, P.191.

Aiken LH, Sloane DM, Kanai-Pak M, Poghosyan, L (2010). Poor work environments and nurse inexperience are associated with burnout, job dissatisfaction and quality deficits in Japanese hospitals. J Clin Nurs;(17), P.3324-3329.

Aldaqal, S., Alghamdi, H., AlTurki, H., Eldeek, S. and Kensarah, A. (2012):Determinants of Patient Satisfaction in the Surgical ward at a University Hospital in Saudi Arabia, Life Science Journal, 9(1): P. 277-280.

Atencio BL et al (2005): Nurse retention: is it worth it? Nursing economics, 21(6): P . 262-274.

Bakker, E. Demerouti, A.I. Sanz-Vergel (2014): Burnout and work engagement: The JD-R approach Annual Review of Organizational Psychology and Organizational Behavior, 1 (2014), P . 389-411.

Bakker, E. Demerouti (2014): Job demands-resources theory P.Y. Chen, C.L. Cooper (Eds.), Work and wellbeing: Wellbeing: A complete reference guide, Vol. IIIWileyBlackwell, Chichester, UK , P . 37-64.

Breevaart, K., Bakker, A. B., Hetland, J., Demerouti, E., Olsen, O. K., \& Espevik, $\boldsymbol{R}$.(2014). Daily transactional and transformational leadership and daily employee engagement. Journal of Occupational and Organizational Psychology, 87, P .138-157.

Edwards D, Burnard P, (2004): A systematic review of stress and stress management interventions for mental health nurses. Journal of advanced nursing, 42(2), P . 169200.

El Awa, B., Habib, S., and El Deek, M. (2011): The Impact of Accreditation on Patient Safety and Quality of Care as Perceived by Nursing Staff in a University Hospital in Saudi Arabia. Research Journal of Medical Sciences, Volume: 4 Issue: P . 319-323. 
Fry, S, \& Veatch, $R \&$ Taylor, C.(2011): Case studies in nursing ethics , $4^{\text {th }}$ ed , Philadelphia. Jones and Bartlett publishers company, P . 120.

Giacaman, R.(2000): Health conditions and services in the West Bank and Gaza strip . Geneva, United Nations, P . 115 - 202.

Gilles, D.A, (2009): "Nursing management A system approach"1노 ed, W.B.Saunder Company, P . $134-249$.

Hakanen, J. J., \& Schaufeli, W. B. (2012): Do burnout and work engagement predict depressive symptoms and life satisfaction? A three-wave seven-year prospective study. Journal of Affective Disorders, 141, P . 415-424.

Happell B (2009): Job satisfaction and burnout: a comparative study of psychiatric nurses from forensic and a mainstream mental health service. International journal of mental health nursing, 12: P . 39-47.

Hatamizadeh, $N$.(2011): Factors affecting Client Satisfaction and Dissatisfaction in Out Patient Rehabilitation Centers in Kurdistan Province in Iran, Iranian Red Crescent Medical Journal, 14(2): P . 119-120.

Khodadadizadeh, A., Ravari, A. Sayadi, A.,khodadadi, H. and Jafarinaveh, $\boldsymbol{H}$. (2012): Occupational burnout assessment among nurses working in Iranian hospital of Ali-ebn Abitaleb, Rafsanjan- Iran: JOHE, Summer, (1). P . 2.

Laschinger, H. K. S., Wong, C. A., \& Grau, A. L. (2012a): Authentic leadership, empow-erment and burnout: a comparison in new graduates and experienced nurses. JNurs Manage, P . 220-230.

Lasebikan, V.O; Oyetunde, M.O (2012): Burnout among nurses in a Nigerian general hospital: Prevalence and associated factors. ISRN Nurs, P . 1-6.

Leiter, M. P., \& Maslach, C. (2014). Interventions to prevent and alleviate burnout. In M. P. Leiter, A. B. Bakker, \& C. Maslach (Eds.), Burnout at work: A psychological perspective. Hove, Sussex: Psychology Press, P . 112. 
Maslache, and Jachson SE. (1981): Maslach burnout inventory In Mahgot N. (Ed) "Assessment of burnout syndrome among hospitals staff nurses and doctors" scientific nursing congress on health promotion, Alexandria, P . 11-13.

Nantsupawat, $A$ (2011): Impact of nurse work environment and staffing on hospital nurse and quality of care in Thailand. Journal of nursing scholarship, 43(4), P . 426432.

Norton. D, S. Robertson, R. Anderson. (2010): A Randomized Controlled Trial to Assess the Impact of an Admission Service on Patient and Staff Satisfaction. International Journal of Nursing Practice, 16(5): P . 461-471.

Pineau Stam , H.K.L. Laschinger, S. Regan, C.A. Wong (2013): The influence of personal and workplace resources on new graduate nurses' job satisfaction, P . (167). J Nurs Manag http://dx.doi.org/10.1111/jonm.12113 early view.

Sandström, A., Peterson, J., Sandström, E., Lundberg, M., Nystrom, I.-L., Nyberg,L., \& Olsson, T. (2011):Cognitive deficits in relation to personality typeand hypothalamic-pituitary-adrenal (HPA) axis dysfunction in women withstress-related exhaustion. Scandinavian Journal of Psychology, 52, P . 71-82.

Sharma, R. (2012). Job Satisfaction in teaching profession of higher secondary school's Teachers of Raebaeli. International Educational E-Journal, 1(2), P . 23-27.

-Sheward, L, Hunt J, Hagen S, Macleod M, Ball ,J (2005). The relationship between UK hospital nurse staffing and emotional exhaustion and job dissatisfaction. Journal of Nursing Management; 13: P . 51-60.

Spector, P.E. (1997): Job satisfaction Application, Assessment, Causes and Consequences. Thousand Oakes, CA: Sage, 12(3), P . 176-188.

Suresh K. Sharma*, Pawan K. Kamra (2013): Patient Satisfaction with Nursing Care in Public and Private Hospitals , Nursing and Midwifery Research Journal, Vol-9, No.3, July, P . (733).

-Tarihi G, Tarihi K (2010): "The relationship of job satisfaction and burnout level with quality of life in hospital nurses", Cumhuriyet Medical Journal; 33: P . 144-152. 
Vahey D.C. Alkon L.(2010): Nurse burnout and patient satisfaction. PMC Journal. 42, P. 1157-1166.

Wachter RM. (2010); Patient safety at ten: unmistakable progress, troubling gaps. Health Aff (Millwood).29(1): P . 165-173.

Westermann, C., Kozak, A., Harling, M., \& Nienhaus, A. (2014):Burnout intervention studies for inpatient elderly care nursing staff: systematic literature review. IntJ Nurs Stud, P . 63-71.

Wilson B., Squires M., Widger K., Cranley L. \& Tourangeau A.(2010) Job satisfaction among a multigenerational nursing workforce. Journal of Nursing Management 16 (6), 716-723.Zangaro G.A. \& Johantgen M. (2009) Registered nurses_job satisfaction in Navy hospitals. Military Medicine 174 (1), P . 76-81.

Woodard,J.(2009): Effects of Rounding on patient satisfaction and patient safety on a Medical-Surgical unit. Clinical Nurse Specialist:; Vol 23- Issue (4) : P . 200 - 206.

Yusof, A. M., Yunus, N.K. \& Ghouri, A. M.(2013): Power Motivation, Burnout of Teacher and its Relationship with Student Satisfaction: An Empirical Study at Public Sector University, P . 258. 


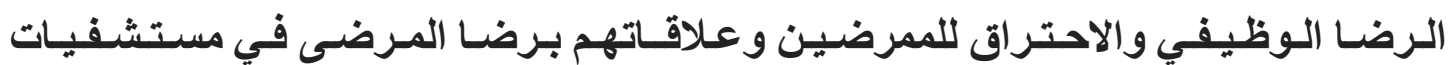

بورسـعيد

أ.د. إيــان سـالـمـان طـايع ، أ.م.د. مني عبد الصبور حسن ، هناء محمد عبد السلام

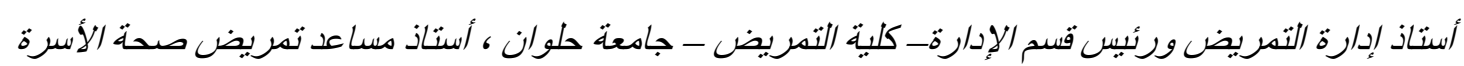

والمجتمع - كلية التمريض - جامعة بورسعبي ، أخصائية تدريض - مستشفي بورسعبد العام

\section{الخلاصة}

ينال الاحتر اق الوظيفي اهتمام واضح فى مهنة التمريض وله تأثير على الممرضين و المرضى، حيث ان طبيعة مهنة التمريض المرهقة تسبب الإنهاك وعدم الرضـا الوظيفي للممرضين. يهرف هذا البحث إلى قياس الرضا الوظيفي و الاحتر اق الوظيفي للممرضين و علاقاتهم برضـا المرضى في مستشفيات بورسعيد ـ تجرى هذه

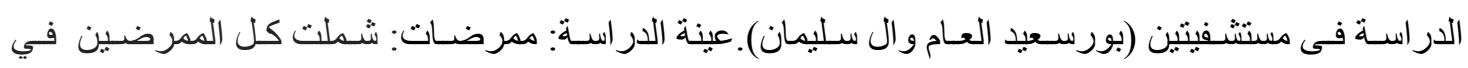
مستشفى بورسعيد العام و مستشفى ال سليمان و عددهم (310) ومرضى: شملت كل المرضى في الأقسام الداخلي

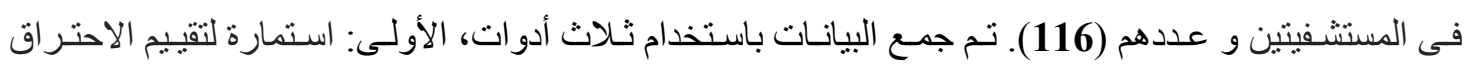

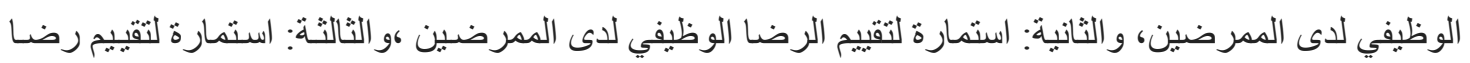
المرضى. و قد أظهرت نتائج الدر اسـة أن أكثر من نصف العدد الكلى للممرضين يعانى من الإنهاك الوظيفي

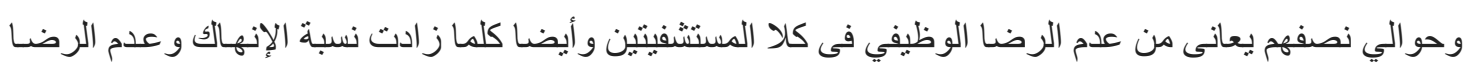
الوظيفي للممرضين في المستشفيات ، يقل رضـا المرضسى. يوجد علاقة سلبية بين الاحتر اق الوظيفي والرضـا

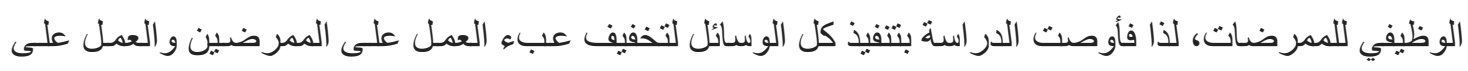
تحسين مرتباتهم وتحسين بيئة العمل.

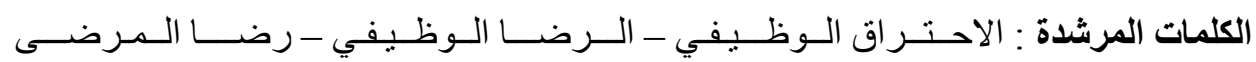

